\title{
A Review on the Application of Flipped Classroom Model in College English Teaching
}

\author{
Liu Haijuan \\ Shaanxi Polytechnic Institute \\ Xian Yang, Shaanxi 712000
}

\begin{abstract}
The application of flipped classroom in college English teaching is an innovation in the new teaching method in line with the current education system of higher education. The flipped classroom model turns the role of teachers and student's upside down, and turns the accepted te aching upside down. It is of certain significance for cultivating students' English learning ability and learning skills. The application of flipped classroom in college English teaching can improve the teaching quality, and it can make students better understand the key and difficult points of English language learning. This is of great significance to the development of English language teaching. This paper starts with the definition of flipped classroom and analyzes the current application of flipped classroom in college English teaching. This paper also puts forward some Suggestions on how to strengthen the construction of flipped classroom in college English. This paper aims to promote the use of flipped classroom in college English te aching.
\end{abstract}

Keywords-College English teaching; Active learning; Flip the classroom.

\section{INTRODUCTION}

As the process of world economic integration deepens, English, as the most popular language in the world, is becoming more and more important. Education is directly oriented to the society and needs to be directly connected with the needs of the society. Therefore, it is increasingly important to strengthen students' English level. Due to the increasing importance of college English teaching, the corresponding teaching method innovation has also received some attention. The application of flipped classroom model in teaching pays more attention to the value of English as a tool language. In teaching, we should aim at improving students' English ability and pragmatic skills. Therefore, in the actual teaching process, we need to consider students' future development and career environment, cultivate students' habit and awareness of learning English, strengthen students' perception of English, and then form good English learning ability, so as to improve the effectiveness of college English teaching.

\section{OVERVIEW OF FLIPPED CLASSROOM}

\section{A. Definition of flipped classroom}

Flipped Classroom, which is translated from "adobe Classroom" or "Inverted Classroom", is a teaching method that reverses the order of traditional Classroom teaching. This model mainly redistributes the resources in and out of class in the teaching process and improves students' learning initiative. The flipped classroom is different from the traditional classroom in the way of teaching, the idea of teaching and the process of teaching. This realizes the exchange of roles between teachers and students. At the same time, the idea of "paying attention to process and not demanding results" is also emphasized in teaching. We think the process of teaching is more important than the result. Flipped classroom can fully inherit the spirit of new curriculum reform and will enable students to form correct values and learning concepts.

\section{B. The significance of using flipped classroom for teaching}

Flipped classroom is a new teaching mode, which has positive significance in college English teaching. First of all, it can improve the self-learning ability of college students and improve the teaching atmosphere. The application of flipped classroom is the change of the old teaching environment. In the past college English classes, teachers taught students to listen to the model has been used for many years. Students' interest in English learning cannot be better mobilized. This leads to a lot of students sleeping or playing games in English class. The application of flipped classroom can significantly change the role of students in English classroom teaching. Students, as participants in English teaching, participate in the teaching process with teachers. The two sides have jointly formed a problem-solving teaching process. The teachers spoon-feed method gradually gave way. Students begin to explore and learn on their own initiative. This will make the interaction between teaching and learning more intuitive and can significantly improve students' learning interest and quality.

Secondly, flipped classroom is a reasonable application of college English teaching resources. Most colleges and universities in China have libraries rich in resources. The library is rich in teaching materials and extracurricular reading materials for English, which can include e-books, teaching CDS, English books and newspapers. Some good schools can also log on to the online education platform of European and American universities remotely, realizing the dream of learning in the English learning environment. Students need to consult more materials in the flipped classroom, and use different education platforms and education resources to expand their English knowledge and ability. This reflects the change of teaching objective from knowledge standard to ability standard. In the long run, flipped classroom can realize the improvement of students' learning ability, and then realize the original goal of cultivating comprehensive talents in education. 
III. APPLICATION OF FLIPPED CLASSROOM IN COLLEGE ENGLISH TEACHING

\section{A. Application of flipped classroom in the pre-teaching stage}

The preparation for flipped classroom is closely related to the characteristics of flipped classroom. The specific content we need to prepare includes the material arrangement, preview, pre-class question, new class introduction and so on. As a result of high school English curriculum content, involving heat, mechanics, optics and other different types. Therefore, when preparing for teaching, we should make clear the key points of different teaching contents. For example, for the teaching of Unit1 Writing for myself unit of new horizons university English, we should make full use of the basic teaching modules constructed by teaching materials, such as Objectives, Time all ordination, etc., and arrange corresponding teaching introduction. In the past, students only focused on the text and vocabulary, ignoring the teaching objectives, teaching schedule and the deepening of teaching content and other related links. In order to better improve flipped classroom teaching, we need to deploy the inquiry link before class. Teachers should guide students to use multimedia tools or library resources for pre-class preparation. After the students have finished the preview, before the formal course begins, the teacher should ask questions or arrange free discussion for the key content of the teaching. It is clear that 'the generation of the changing magnetic field comes from the changing current, and the changing magnetic field in the changing process not only changes the direction and strength of the current, but also has a certain impact on the stressed objects moving in the magnetic field. At the same time, ask the students to put forward a series of problems or problems to be solved to start an English class.

\section{B. Application of flipped classroom in teaching}

The appearance of flipped classroom enables students to realize personalized learning more specifically. First, the learning environment is more personalized. Compared with the traditional classroom, flipped classroom is easier to achieve the interactive teaching atmosphere between teachers and students. By reducing the amount of time, a teacher gives to a class, the teacher leaves most of the time to the students in an English class. The content of students can be based on the views of the relevant content of the course, independent reports, class discussions, and questions answered each other. For example, the teacher explains the important Reading skills to the students. The teacher explains the key points and difficulties. Based on the specific types of questions, the main questions of students in the following "individual exercises" were defined. Students could find the answers to the questions raised by teachers through reading instead of directly answering them.

The practical application of flipped classroom needs the assistance of modern education system, such as the application of multimedia for teaching. The flipped classroom model is intended to realize students' good adaptability in the learning environment. It is helpful for students to be familiar with the basic sentence structure and understand the basic components of sentences. All is not gold that glitters, He who does not reach the Great Wall is not a Great man. At the same time, we can also focus on the translation of Chinese and English. By analyzing and translating common sentences, students can better master knowledge. This also reduces the burden of teaching. In the process of flipped classroom teaching, the elaboration of concepts should focus on students' inquiry and avoid indoctrination. Therefore, teachers should pay attention to the construction of learning tasks, further improve and expand teaching, and pay attention to the construction of students' ability to draw inferences.

In addition, teachers should pay more attention to the application of diversified resources in the actual teaching process. The realization of flipped classroom depends on the support of multimedia resources. It is because of this trend that students have more diversified access to knowledge. English teaching, which is limited to classroom and textbook knowledge, is not conducive to students' understanding of English knowledge and application environment. The flipped classroom combines different teaching resources and models such as video teaching, interactive teaching and situational teaching to realize the introduction of diversified teaching resources. For college English learning, students need to have good thinking ability and habits due to the increasing difficulty and content. Students need to think in a diversified and profound way through specific things and materials. Through the study of an English class, students should have a comprehensive understanding of the corresponding concepts and application scenarios.

\section{Application of flipped classroom after teaching in the post - teaching reflection}

"Homework" is an important teaching link which cannot be neglected to improve the teaching quality. "Homework" is a process in which students reproduce, sort out and process the information they receive. "Homework" is also the process of consolidating students' knowledge and exercising their thinking. At the same time, the information transmission between teachers and students depends largely on homework. Good homework mode requires teachers to start from the link of assigning homework, attach importance to competency standard and student standard, and promote the scientific of assigning and correcting homework in a more scientific and reasonable way. The way teachers grade English homework is also of great significance. The process of grading is a process of dialogue with students. The teacher should change the previous posture, and use English language to talk with the students, and annotate the problems and deficiencies in his homework, as well as guide the thoughts and draw the thinking map. Because the student does the homework error often is to be not quite familiar with a certain kind of problem. The teacher guides and helps the students in the homework to make them clear their deficiencies faster and to get promoted as soon as possible. At the same time, students can also discuss and communicate with teachers about the notes of homework to form a better teaching and learning atmosphere.

Teachers also need to reflect after finishing a lesson. The teacher thinks about the design of flipped classroom and whether the homework can better test the classroom learning results from the students' pre-class preparation and teaching process. When necessary, the teacher should write a summary 
of classroom teaching and form a feedback mechanism in a timely manner. Teachers should have some discussions with students about the teaching process, so as to improve the application of flipped classroom in later teaching.

\section{MEASURES TO IMPROVE THE APPLICATION OF FLIPPED CLASSROOM IN COLLEGE ENGLISH TEACHING}

\section{A. Cooperative learning to improve students' independent learning ability}

In previous English classes, teachers often paid little attention to the effect of students' pre-class preparation and homework after class. This method can certainly let us clearly see the student's study effect. But we should also see that college students are in the construction and development stage of knowledge ability. Although they have developed significantly in perceptual activities and abstract logical thinking, they are still immature. In addition, they have different learning abilities for different English contents. Therefore, when students complete the learning of English contents alone, they tend to not consider the problems carefully enough, ignore the key points, and fail to complete a series of learning tasks such as translation and oral English training smoothly. In order to cultivate students' independent learning ability, they should strengthen their sense of task. By assigning homework in each class and using the flipped classroom teaching model, English task-based teaching and group cooperative learning become teaching practices. While helping each other, each student is required to have his own ideas and tasks. Students are bound to join the active learning process in order to improve their self-learning ability and interest in English classes. In the course of English teaching, teachers should not only stimulate students' interest in learning, but also contact with the reality and pay attention to the cultivation of students' practical application ability. Teachers should not focus only on textbook knowledge. Only in this way can students' learning interest be aroused in English classroom teaching and a flipped classroom teaching model with high innovation can be formed.

\section{B. To attach importance to teaching research and improve the classroom teaching mode}

It should be clear that while the translation of the classroom teaching model does have many advantages, it still requires different schools to make proper arrangements for their own teaching and the acceptance and acceptance of students in the course of practical college English teaching. If the students have a low degree of recognition of flipped classroom teaching patterns, the force of use will lead to the decline of learning efficiency and the quality of teaching. This also suggests that we must strengthen the research and analysis of the flipped classroom teaching mode, and use the results of the teaching research to promote the relaxation mode of the flipped classroom application, so that better students can benefit from the flip class and increase the efficiency of college English teaching.

\section{CONCLUSION}

In conclusion, in college English teaching, teachers should change the traditional teaching mode and concept, apply the flipped classroom, guide the students' society, learn, cultivate the students' independence, autonomy and creativity as the teaching goal, thus, the students' learning ability is greatly improved, and the results of good teaching are obtained.

\section{REFERENCE}

[1] Deng Di. Application of flipped classroom model in college English teaching [J]. Foreign languages,2016(04):89-96.

[2] Xie Mei. Application of flipped classroom model based on micro-class in college English teaching [J]. English square,2016(03):95-97.

[3] Fei Yan. On the application of flipped classroom model in college English teaching [J]. Jiangsu foreign language teaching research,2015(01):37-39.

[4] Lu Haiyan. Feasibility analysis of the application of the "flipped classroom" model based on micro-lectures in college English teaching [J]. Foreign language audio-visual teaching,2014(04):33-36.

[5] Miao Xin, Zhang Jing, Zhang Huiyuan. Application of flipped classroom model in college English teaching [J]. Journal of education college, kaifeng,2014,34(04):92-93. 